\title{
MODEL OF ENGLISH LEARNING BASED ON COLLABORATIVE THEORY TO IMPROVE INDONESIAN' SPOKEN COMMUNICATION ABILITY
}

\author{
Nur Asmawati \\ State Institute for Islamic Studies (IAIN), Palu, Indonesia \\ nurasmawaty74@gmail.com
}

\begin{abstract}
The objective of this study is to know the effects of collaborative learning model; theory of behaviorism, cognitivism and constructivism on the improvement of English spoken communication ability. This study used quasi experimental design with Posttest-Only, Non-Equivalent Control Group Design. The sample of this research were students of State Institute for Islamic Studies (IAIN) Palu. The instrument in this research was speaking English test ability. The tests were carried out in five times with different learning themes. Data analysis was performed by descriptive and inferential statistics and presented in the form of percentages, frequency, mean and statistical analysis in $t$ test comparison ( $t$-test. The researcher finds distribution of scores for the students' spoken communication ability posttest is normal and variance-covariance for the dependent variables is homogeneous across the independent variables. The researcher finds a significant difference between the experimental class taught by a learning model of three theories collaboration and control class taught by conventional learning model. The result of students' spoken communication ability on first test had higher compared second test. Similarly, also with the students' spoken communication abilities between the second tests with the third test, the third test with the fourth test, and the fourth test with the fifth test was very significant. The researcher also finds that there is an increase of English spoken communication ability after teaching using model of learning English based on collaborative theory
\end{abstract}

Keywords: Collaborative Learning Model, Theory, English Spoken, Communication Ability.

\section{A. INTRODUCTION}

$\mathrm{I}$

$\mathrm{n}$ daily life, people need more time to communication. The most dominating forms of communication in social life is an oral communication. People need communication with others in providing information, obtain information, or even entertaining. Language is an important medium of communication in human life. As a means of communication that language is unique and universal. In reality, the only man is capable of communicating verbally. Language serves as a symbolic language, emotive and affective. As well as in the world of language, education is an instrument of transformation of science and knowledge.

English is one of the languages widely spoken in the world. Graddol (1997: 10) mentions that there are three levels of English speakers: (a) the first-language speakers to the number of s320- 
380 million, (b) the second-language speakers to the number of 150-300 million, and (c) the foreign-language Speers to the number of one billion. Tonkin (2003:16) assumes that the only people who think that one can conduct all of one's affairs in this world through the medium of a single language are speakers of English. They feel as they do because of the notable spread of the English language in modern times to almost all corners of the globe and almost all domains of human endeavor. English is also the world's most studied language. There are hundreds of millions of people across the world who are studying or have studied the language.

Some countries have realized that the capability to master English is essential life skills for their countries in the future. Therefore, it cannot be denied that they develop English in their educational curriculum. In Indonesia, since the independent day, English has become a curriculum content which is inserted starting from the primary level up to the college. Durand (2006: 7) argues that mastering English is very important because almost all global resources of various aspects of life using English.

The State Institute for Islamic Studies (IAIN) Palu as an educational institution which adopts English as the core curriculum teaches English as a tool to explore Islamic sciences or related skills such as education, Islamic law and Islamic communication. This approach is known as English for Specific Purposes (ESP). The main characteristics of ESP are: (1) Designed for adult learners, (2) To provide skills in accordance with the specifications of occupational profession, (3) It is usually given in a relatively homogeneous class. (4) It begins with a need analysis (Alwasilah 2010:119). The linkage between the ESP and oral communication competence can be attributed to the growing number of job opportunities for graduates of IAIN. For example, some Islamic diplomats in Muslim countries require graduates who are not only proficient in English, but also proficient in Arabic languages, and know about the science of religion. Teachers of Islamic Education in International Standard School (SBI) are required to master oral English communication as the medium of Islamic religious education. Syari'ah businesses, increasingly expanding worldwide also requires that.

In the context of the implementation of the English curriculum, since 2010 IAIN has applied the new curriculum, the Competence Based-Curriculum. However, the government does not intervene directly with the curriculum which needs to be developed. Besides, the curriculum applied in IAIN Palu, does not include the instructional material. 


\section{Volume 4, Number 2, December 2018}

\section{B. LITERATURE REVIEW}

Zaky (2011) have conducted research on the English curriculum and instructional design in some Islamic Higher Educations (PTAI) in Tasikmalaya. This study revealed that the design of KPKL curriculum and instructional material can help teacher performance in teaching and also the students' ability in oral communication compared by conventional curriculum.

The research findings above, shows the importance of improving the students' communication competency in English both curriculum and learning. Th is consistent with that proposed by Durand (2006:7) that mastery of language English is very important because almost all global resources various aspects of life using this language.

Learning is a system that consists of various components that are interconnected to one another. Such components include objectives, materials, methods and evaluation. Model of teaching are usually prepared on various principles or theories as basic in its development. Furthermore, the experts create a model of teaching based on educational principles, theory of psychological, sociological, learning, and systems analysis (Joyce, Weil, \& Calhoun, 2003). In addition, Joyce, Weil, \& Calhoun, ( 2003) state that a model of teaching is a plan or pattern that can be used to shape curriculum (long-term course of studies), to design instructional materials, and to guide instruction in the classroom and other setting. The task of selecting appropriate model is complex and that the forms of "good" teaching are numerous depending on the learning objectives.

With such views, learning theories are needed to understand the inherently complex process of learning and how to best teaching instruction, training and other education processes. Learning theory assist planners in making learning model (Azis 2006:13).

There are three main perspectives in learning theory, namely Behaviorism, Cognitivism, and Constructivism. Basically, the first theory furnished by other theories, so there are variants, the main idea, or character that cannot be put clearly belong to which, or even become its own theory. However, this does not need to argue about. What is more important for us to understand is where a good theory to be applied to certain areas, and where appropriate theory to other areas. Such understanding is important to be able to improve the quality of learning.

In Indonesia itself, most learning is still basically applying the conventional education grounded which based on the behaviorism learning theory. Teacher sees the student's mind as a 
"black box", a response to a stimulus can be observed quantitatively, by ignoring the effects of thinking processes that occur in the mind. Therefore, in designing the activity for learning, it focuses on the drill such as "listen and repeat" the expression produced by teacher watched in order that the students form their speaking habit.

Another theory of learning is Cognitivism which focuses on the inner mental activities, opening the "black box" of the human mind is valuable and reviewed as a process in which the learner actively constructs or build necessary for understanding how people mental processes such as thinking, memory, knowing, and problem-solving. The activity is designed to train the students' thinking process by asking the students to discuss an interesting topic.

In Constructivism, learning is viewed as a process in which the learner actively constructs or builds new ideas, concepts, based upon current or past knowledge. In the constructivist classroom, the classroom is no longer a place where the teacher ("expert") pours knowledge into passive students, who wait like empty vessels to be filled. In the constructivist model, the students are urged to be facilitator who coaches, mediates, prompts, and helps students to develop and assess their understanding, and thereby their learning. The designed activity is related to constructivist theory in language learning such as constructing the utterances based on their knowledge to practice their speaking abilities

Teaching model is prepared based on the principles or theories as the basis for the development. Furthermore, the experts make a teaching model based on the principles of education, theory of psychological, sociological, study and system analysis (Joyce \& Weil: 1980). Furthermore, Joyce \& Weil say that the task of selecting the appropriate model is complex and the forms of good teaching depends a lot on learning objectives. With such views, the learning theories are necessary to understand the inherently complex process of learning and how well the instruction process of teaching, training and other educational is. Learning theory helps the planners to make learning model (Azizi 2005: 13).

In Indonesia, learning is basically still a conventional education based on behaviorist learning theory (Budiningsih, 2005: 37). The teachers see the student's mind as a "black box", which the response to a stimulus can be observed quantitatively, by ignoring the effects of the processes that occur in the thinking mind. Therefore, in designing activities for learning, they focus on the 


\section{Volume 4, Number 2, December 2018}

drilling as "listen and repeat" the expressions generated by the lecturers who watch so that the students form their speaking habit.

Another learning theory is cognitivism that focuses on the mental activity of the mind, opens the "black box" of the valuable human mind and reviewed as a process in which the learners actively build or construct to understand how the mental processes of an individual are, such as thinking, memory, knowing, and solving problem (Rumelhart, 1975: 2).

In constructivism learning theory, learning is seen as a process in which the learners actively build or construct new ideas, concepts, based on current or past knowledge (Brinner, 1999: 1). In the constructivist class, the class will no longer be a place where teachers ("experts") pour the knowledge into passive students, who wait like an empty vessel to be filled. In the constructivist model, the students are asked to be a facilitator who become coaches, mediates, prompts, and helps students develop and assess their understanding, as well as their learning. These activities are designed with regard to the constructivist theory in learning language such as building the speech based on their knowledge to practice their speaking ability.

Based on the background above, the research examines the development of learning model for the students at State Institute for Islamic Studies (IAIN) based on learning theories of behaviorism, cognitivism and constructivism.

\section{RESEARCH METHOD}

The study is quasi experimental design with Posttest-Only, Non-Equivalent Control Group Design. The design of this study consists of one experimental group (Collaborative Model) and one control group (Conventional Model). The design of this was chosen because the present study used intact groups as subjects (Wiersma, 2000 : 67). The English spoken communication ability exercise in the form of an interview had been used as a means of data collection. Posttest is performed 5 times with different themes. Data analysis is performed by descriptive and inferential presented in the form of percentages, frequency, mean and statistical analysis in t test comparison (t-test) and Pearson correlation test. 


\section{FINDINGS AND DISCUSSION}

\section{Descriptive Analysis}

The researcher finds that the average spoken communication ability of the class taught by Collaborative Theory Model is higher compared to speaking skills taught by Conventional Model on each posttest (see Table 1).

Table 1. Spoken English Communication Ability

\begin{tabular}{cccccc}
\hline Posttest & \multirow{2}{*}{ N } & \multicolumn{2}{c}{ Control } & \multicolumn{2}{c}{ Experimental } \\
\cline { 3 - 6 } & 30 & 25.92 & 3.04 & 42.96 & 5.53 \\
\hline $\begin{array}{c}\text { Posttest 1 } \\
\text { (Allah is God) } \\
\text { Posttest 2 }\end{array}$ & 30 & 26.85 & 3.28 & 47.96 & 6.67 \\
$\begin{array}{c}\text { (Our prophet is Muhammad) } \\
\text { Posttest 3 }\end{array}$ & 30 & 26.07 & 3.16 & 49.99 & 5.92 \\
$\begin{array}{c}\text { (Angel and Jin are Creature) } \\
\text { Posttest 4 }\end{array}$ & $\mathbf{3 0}$ & $\mathbf{3 7 . 7 7}$ & $\mathbf{3 . 2 4}$ & $\mathbf{5 6 . 3 0}$ & $\mathbf{5 . 6 2}$ \\
$\begin{array}{c}\text { (Qur'an is Holly Book) } \\
\text { Posttest 5 }\end{array}$ & $\mathbf{3 0}$ & $\mathbf{3 4 . 0 7}$ & $\mathbf{3 . 0 2}$ & $\mathbf{6 2 . 2 2}$ & $\mathbf{5 . 8 2}$ \\
$\begin{array}{c}\text { Our Foundation is Islamic } \\
\text { Pillar }\end{array}$ & & & & & \\
\hline
\end{tabular}

For example, on the theme of Allah is God, in the posttest (Mean $=42.96, \mathrm{SD}=5.53)$ of the experimental group taught by learning model of collaborative theory, the mean is larger than the control class $($ Mean $=25.92, \mathrm{SD}=3.04)$. At the sixth posttest with the theme of "our foundation is the Islamic pillar" material, the test result of the experimental group (mean $=62.22, \mathrm{SD}=5.82$ ) is still larger compare to the control group (mean $=34.07, \mathrm{SD}=3: 02$ ).

Researcher finds in the experimental group, there is a consistent increase in contrast to the control group which the results are inconsistent. 
Volume 4, Number 2, December 2018

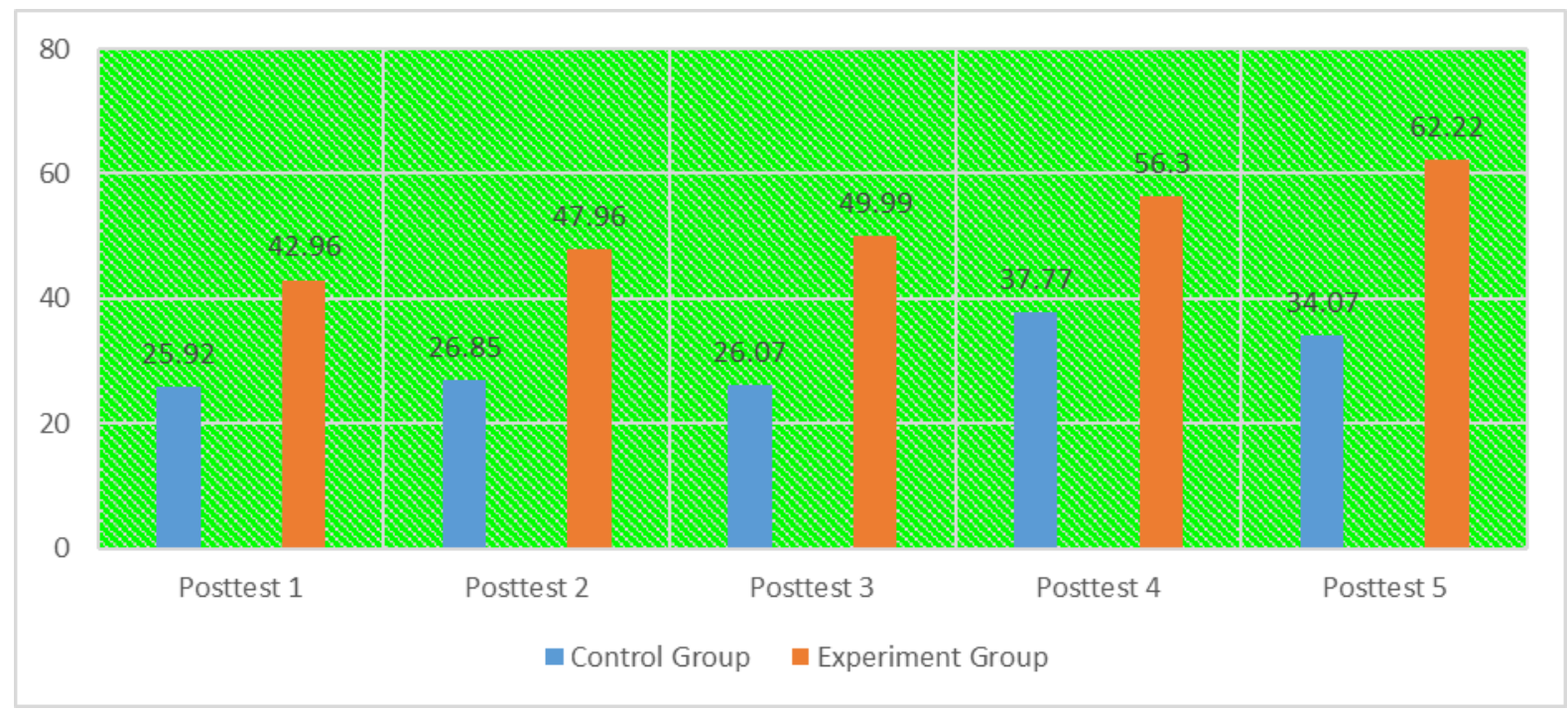

Figure 1. Ability of Spoken Communication

2. Requirements analysis

Kolmogorov Smirnov analysis is conducted for test of spoken communication ability (see Table 2).

Table 2. Kolmogorov Smirnov Analysis for spoken communication ability

\begin{tabular}{clccc}
\hline $\begin{array}{c}\text { Ability of spoken } \\
\text { Communication }\end{array}$ & \multicolumn{1}{c}{ Group } & Statistics & Df & Sig \\
\hline 1 & Experimental & 0.074 & 30 & 0.200 \\
\multirow{2}{*}{2} & Control & 0.070 & 30 & 0.062 \\
& Experimental & 0.092 & 30 & 0.852 \\
\multirow{2}{*}{3} & Control & 0.085 & 30 & 0.200 \\
& Experimental & 0.087 & 30 & 0.064 \\
& Control & 0.077 & 30 & 0.085 \\
\multirow{2}{*}{5} & Experimental & 0.074 & 30 & 0.200 \\
& Control & 0.073 & 30 & 0.056 \\
& Experimental & 0.080 & 30 & 0.092 \\
& Control & 0.076 & 30 & 0.107 \\
\hline
\end{tabular}

The finding reveals a significance value on the spoken communication ability posttest 1 (Allah is God) experimental group of $\mathrm{p}=0.200$ and the control group of $\mathrm{p}=0.062$. The values for the spoken communication ability first posttest for both the groups were $p>0.05$. Similarly, 
for second, third, fourth and fifth posttest's scores $\mathrm{p}>0.05$. These findings show that both the experimental and control groups are homogenous, and treatment could be applied to these groups as a mean of identifying differences caused by the treatment.

Because all significance values are $\mathrm{p}>0.05$, the distribution of scores for the spoken communication ability posttest is normal. As a conclusion, treatment could be applied to both groups to determine differences of the effect between the groups.

\section{Analysis of Homogeneity}

A two-way ANOVA is conducted to determine differences in posttest between the experimental and control groups based on spoken communication ability. Before the analysis is performed, a Levene's test is conducted to test similarities that existed among variables (see Table 3).

Table 3. Test of Homogeneity of Variances Posttes

\begin{tabular}{cccc}
\hline F & df1 & df2 & $P$ \\
\hline 2.181 & 2 & 87 & 0.119 \\
\hline
\end{tabular}

The finding reveals no significant variance-covariance differences among the dependent variables for all levels of the independent variables, $F=2.181, \mathrm{p}>0.05$. This finding could be interpreted as variance-covariance for the dependent variables is homogeneous across the independent variables. Therefore, the one-way ANOVA is performed to determine differences that exists between the experimental and control groups in terms of spoken communication ability (Pallant, 2007)

\section{Analysis of Independent t-test}

Independent t-test to determine the differences of students' spoken communication ability between the experimental class and control class. There is a significant difference between the spoken communication ability of the students between an experimental class taught by with a 


\section{Volume 4, Number 2, December 2018}

learning model of three theories collaboration and a control class that is taught by a conventional model (cognitive tendencies). See Table 4.

Table 4. Posttest Between Control Class and Experimental Class

\begin{tabular}{|c|c|c|c|c|c|c|c|c|}
\hline \multirow[t]{2}{*}{ Posttest } & \multirow[t]{2}{*}{$\mathrm{N}$} & \multicolumn{2}{|c|}{ Control Group } & \multicolumn{2}{|c|}{$\begin{array}{l}\text { Experimental } \\
\text { Group }\end{array}$} & \multirow[t]{2}{*}{$t_{\text {cal }}$} & \multirow[t]{2}{*}{$\mathrm{P}$ value } & \multirow[t]{2}{*}{ Eta Squared } \\
\hline & & Mean & $\mathrm{SD}$ & Mean & SD & & & \\
\hline $\begin{array}{c}\text { Posttest } 1 \\
\text { (Allah is God) }\end{array}$ & 30 & 25.92 & 3.04 & 42.96 & 5.53 & 11.58 & 0.000 & 0.19 \\
\hline $\begin{array}{l}\text { Posttest } 2 \\
\text { (Our prophet is } \\
\text { Muhammad) }\end{array}$ & 30 & 26.85 & 3.28 & 49.99 & 6.67 & 9.06 & 0.000 & 0.18 \\
\hline $\begin{array}{c}\text { Posttest } 3 \\
\text { (Angel and Jin are } \\
\text { Creature) }\end{array}$ & 30 & 29.07 & 3.16 & 47.96 & 5.92 & 16.44 & 0.000 & 0.22 \\
\hline $\begin{array}{c}\text { Posttest } 4 \\
\text { (Qur'an is Holly } \\
\text { Book) }\end{array}$ & 30 & 37.77 & 3.24 & 56.29 & 5.62 & 20.45 & 0.000 & 0.16 \\
\hline $\begin{array}{l}\text { Posttest5 } \\
\text { Our Foundation is } \\
\text { Islamic Pillar }\end{array}$ & 30 & 34.07 & 3.02 & 62.22 & 5.82 & 23.06 & 0.000 & 0.26 \\
\hline
\end{tabular}

The table shows that there are significant differences $(t=11584, \mathrm{p}=0.000)$ of the spoken communication ability between the experimental class (mean $=37.77 ; \mathrm{SD}=5,538$ ) and control class (mean $=25$ 926; SD = 3,038).

The fifth test shows that there are significant differences $(t=23: 06, p=0.000)$ of the spoken communication ability between the experimental class (mean $=62.22$; $\mathrm{SD}=5.82$ ) and control class $($ mean $=34.07 ; \mathrm{SD}=3: 02)$.

5. ANOVA Test for Experimental Class

According to the ANOVA table it is found that the significant differences $[\mathrm{F}(2.87)=$ $21,175, \mathrm{p}=0.000$ among the five tests of spoken communication ability for the experimental 
class with a large size effect (Eta Squared $=0.327)$. To ensure that these differences are statistically significant, one-way ANOVA test is conducted (see Table 4).

Table 4. Test of One - Way ANOVA

\begin{tabular}{lccccc}
\hline Independent Variable & jum of Squares & Df & Mean Square & F & $P$ \\
\hline Between Groups & 1557.556 & 2 & 778.778 & 21.175 & 0.000 \\
Within Groups & 3199.641 & 87 & 36.777 & & \\
& 4757.197 & 89 & & \\
\end{tabular}

The finding reveals significant differences in spoken communication ability between the experimental and control groups, $\mathrm{F}=21.175$ and $\mathrm{p}=0.000$. To examine these differences further, a Pos Hoc Scheffe analysis was performed (see Table 5).

Table 5. Pos Hoc Scheffe Differences in spoken communication ability

\begin{tabular}{|c|c|c|c|c|}
\hline (I) posttest & (J) posttest & Mean Difference (I-J) & Std. Error & $P$ \\
\hline \multirow{4}{*}{1} & 2 & $-5.18907^{*}$ & 1.56583 & 0.004 \\
\hline & 3 & $-10.18947^{*}$ & 1.56583 & 0.000 \\
\hline & 4 & $-5.7293^{*}$ & 1.41141 & 0.001 \\
\hline & 5 & $-8.2237^{*}$ & 1.59010 & 0.000 \\
\hline \multirow{4}{*}{2} & 1 & $5.18907^{*}$ & 1.56583 & 0.004 \\
\hline & 3 & $-5.00040^{*}$ & 1.56583 & 0.006 \\
\hline & 4 & $-5.4944^{*}$ & 1.37833 & 0.006 \\
\hline & 5 & $-9.8977^{*}$ & 1.45512 & 0.000 \\
\hline \multirow{4}{*}{3} & 1 & $10.18947^{*}$ & 1.56583 & 0.000 \\
\hline & 2 & $5.00040^{*}$ & 1.56583 & 0.006 \\
\hline & 4 & $-7.0678^{*}$ & 1.42242 & 0.000 \\
\hline & 5 & $-8.7894^{*}$ & 1.55612 & 0.000 \\
\hline \multirow{4}{*}{4} & 1 & $5.7293^{*}$ & 1.41141 & 0.001 \\
\hline & 2 & $5.4944^{*}$ & 1.37833 & 0.006 \\
\hline & 3 & $7.0678^{*}$ & 1.42242 & 0.000 \\
\hline & 5 & $-5.7895^{*}$ & 1.57689 & 0.001 \\
\hline \multirow{4}{*}{5} & 1 & $8.2237^{*}$ & 1.59010 & 0.000 \\
\hline & 2 & $9.8977^{*}$ & 1.45512 & 0.000 \\
\hline & 3 & $8.7894^{*}$ & 1.55612 & 0.000 \\
\hline & 4 & $5.7895^{*}$ & 1.57689 & 0.001 \\
\hline
\end{tabular}




\section{Volume 4, Number 2, December 2018}

The results yielded significant differences in spoken communication ability on experiment group between first test and second test, $\mathrm{p}=0.004$. In terms of mean, spoken communication ability on first test had higher compared second test with a mean difference of 5.18907. Similarly, also with spoken communication abilities between the second tests with a third test, test third and fourth test, fourth test with the fifth test was very significant. This means that oral communication abilities on each test experienced a significant improvement for the experimental group.

In the independent t-test, it shows significant differences in five tests between the experimental classes with control class. The mean of oral communication skills of the students taught by learning model combination based on theory of behaviorism, cognitivism and constructivism is higher compare to the students taught by the tendency of cognitivism learning model only (conventional model). The findings of this study are supported by the research conducted by Kop, R., and Hill, A. (2008) that learning with many learning theories approach will be more varied and attractive so it encourages the students to be motivated in learning and following the course, it also will affect the learning outcome. Learning models and systems that emphasize more on cognitive approaches alone cause a classroom atmosphere which is static, monotonous and boring, and the greater concern is they will "turn off" the activity and creativity of the students in the classroom. This learning model in Paulo Friere paradigm known as banking learning concept (Paulo Ferire, 2008: 54), where the learners are given a wide range of knowledge and information by the teacher by ignoring the activity and creativity of learners in class. Then the learners are considered and positioned as "container object" of the insight and knowledge of the teachers and then the results will be seen at the end of the learning process

From test to test there is a significant improvement, this suggests that the treatment of learning model based on three theories of behaviorism, cognitivism and constructivism give impacts to spoken oral communication ability of the students. Krashen (1981: 81) argues that learning models with a variety of approaches and methods can consistently improve the English skills of the students.

Danic et al. (2000) suggested that collaboration in learning can be used as learning models. This is in accordance with Zacky study (2011) which states that in the English language learning model can improve spoken English ability of students in The State Institute for Islamic Studies. 


\section{E. CONCLUSION}

The use of a collaborative learning model theory of behaviorism, cognitivism and constructivism can improve English spoken communication ability of the students of State Institute for Islamic Studies (IAIN) Palu. Therefore, in the learning implementation in the classroom, the lecturers need to use different learning theory collaboration so that the learning process become more varied in the class. A learning model that tends to use only one learning theory, for instance only on the tendency of the reading cognitive learning theory alone will cause the learning becomes monotonous and unappealing. It affects to the oral communication skills of the students. With the learning model based on three theories of behaviorism, cognitivism and constructivism, it has been shown to provide the effect on the ability of the students of Islamic Education program in English spoken communication.

\section{REFERENCES}

Alwasilah, A. Chaedar. (2010). Language, Culture, and Education, A Portrait of contemporary Indonesia. Bandung. Ning Devices. Andira.

Azis, E. Aminuddin. (2006). Indonesia English: what's de tuh?, dalam jurnal TEFLIN. www.trflinindonesia.org

Brinner, J. (1999). Postmodernism and Constructivism. http://curriculum.calstatela.edu/faculty/psparks/theorists/htm.

Brown, H. Douglas. (2008). Prinsip Pembelajaran dan Pengajaran Bahasa. Jakarta: Kedutaan besar Amerika Serikat di Jakarta dan Pearson Inc.

Budiningsih, A. (2005). Belajar dan Pembelajaran. Jakarta: Rineka Cipta.

Danic M,Orchovacki T,Stapic Z.(2000).Introducing CaCM: toward new students collaboration model. Pavlinska: Faculty of Organization and Informatics University of Zagreb.

Dillenbourg, P., (1999). "Collaborative Learning: Cognitive and Computational Approaches," (Advances in Learning and Instruction Series), New York, NY: Elsevier Science.

Durand, C. X. (2006). If it's not in English, it's not worth reading! Current Issues in Language Planning, 7(1), 44-60.

Ertmer, P.A., \& Newby, T.J. (1993). Behaviorism, cognitivism, constructivism: Comparing critical features from an instructional design perspective. Performance Improvement Quarterly, 6(4), 50-72.

Fatihi, A.R. (2003). The Role of Needs Analysis in ESL Program Design" South Asian Language Review. 13 (1\&2) 39-59.Available at http:// salr.net/documents/ fatihi.pdf.]september 20 ${ }^{\text {th }}$,2007).

Ferire, Paulo. (2008). Pendidikan kaum Tertindas, Jakarta: LP3ES,

Gall Meredith D, Gall Joyce P, and Borg. (2003).Educational Research. Boston. Pearson Education, Inc.

Graddol, D. (1997). The future of English. London: The British Council. 


\section{Volume 4, Number 2, December 2018}

Graddol, D. (2006). English next. Retrieved December 12, 2015, from www.britishcouncil.org/files/documents/learning-research-english-next.pdf

Hendryanti, R. (2007). Materials Development of an EFL Reading Courseware for $8^{\text {th }}$ grade students. Unpublished master's degree thesis, English Education ProgramGraduate School, Indonesia Institute of Education.

Jenkins, E. W. (2000). Constructivism in school science education: Powerful model or the most dangerous intellectual tendency? Science \& Education, 9, 599-610.

Johnson, B. \& Christensen, L. (2000). Educational Research: Quantitative and Qualitative approaches. Boston: Allyn and Bacon Company.

Joyce, B \& Marsha Weil. (2000). Metode of Teaching. Prentice-Hall, Inc. Englewood Cliffs, New Jersey.

Pallant, J. (2007). SPSS Survival Manual: A Step by step guide to data analysis using SPSS Third Edition. Australia: Allen \& Unwin.

Kop, R., \& Hill, A. (2008). Connectivism: Learning theory of the future or vestige of the past? International Review of Research in Open and Distance Learning, 9(3). Retrieved January 20, 2009, from http://www.irrodl.org/index.php/irrodl.

Kellem, H. 2009. "Principles for Developing Oral Fluency in the Classroom”. JALT Journal 33 (1): 9-11

Kim, C., \& Hatton, N. (n.d.). Cognitive theory and curriculum application. Retrieved January 21, 2014 ,

from http://www.umm.maine.edu:300/education/students/curriculumDesign/Hatton.htm.

Krashen, S. (1981). Second Language Acquisition and Second Language Learning. Retrieved from http://sdkrashen.com/SL Acquisition and Learning/SL Acquisition and Learning.pdf.

Mubarak, Ahmad Zaky, (2011). Model Kurikulum dan Pembelajaran Bahasa Inggeris Untuk. Meningkatkan Kemampuan Lisan .Studi Pengembangan Kurikulum. Unpublished Dissertation. Bandung. Universitas Pendidikan Indonesia

Murphy, D.F. (1985). "Evaluation in Language Teaching: Assesment Accountability and Awareness". In J.C. Alderson (Ed), Evaluation, Lanchaster Practical Papers in English Language Education 6 (pp: 1- 17). Oxford: Pergamon Press.

Riyandari, Angelika.(2006). Challenges in Implementing Competency-based English Language Teaching at Institute Level Journal TEFLIN di www.tefli-indonesia.org.

Rumelhart, D.E. (1975). Notes on a Schema for Stories. In D.G. Bobrow and A Collins (ed). Representation and Understanding: Studies in Cognitive Science. New York: Academic Press.

Savignon, S.J. (2002). Interpreting Communicative Language Teaching. New Haven \&London: Yale Institute Press.

Stahl, G., Koschmann, T., \& Suthers, D. (2006). Computer-supported collaborative learning: An historical perspective. In R. K. Sawyer (Ed.), Cambridge handbook of the learning sciences. (pp. 409-426). Cambridge, UK: Cambridge University Press. Web: http:/ /GerryStahl.net/elibrary/global.

Tonkin, H. (2003). Language and Society. http://www.globaled.org/issues/178F.pdf. June 9, 2015].

Wiersma, W. (2000). Research Method in Education: An introduction. Needham Heights: Allyn and Bacon.

Yahaya, Azizi.et.al. (2005). Psikologi Kognitif.Johor: Universiti Teknologi Malaysia. 